\title{
Creative Character Training (CCT): Dampaknya terhadap Karakter Kreatif Guru Pendidikan Anak Usia Dini
}

\author{
Iis Sumyati Shalihat ${ }^{\circledR}{ }^{凶}$, Syamsu Yusuf Lili Nanih ${ }^{2}$, Uman Suherman Alamsyah ${ }^{3}$ \\ Psikologi Bimbingan dan Konseling Afiliasi, Universitas Pendidikan Indonesia $(1,2,3)$, \\ DOI: $\underline{10.31004 / o b s e s i . v 6 i 2.1336}$
}

\begin{abstract}
Abstrak
Penelitian ini bertujuan untuk mengetahui dampak Creative Chacarter Training (CCT) terhadap peningkatan karakter kreatif pada guru Taman Kanak-kanak di Kecamatan Coblong Kota Bandung. Penelitian ini menggunakan Exploratory Sequential Mixed Methods Design. Partisipan dalam penelitian ini adalah 13 orang guru PAUD di Kecamatan Coblong, Kota Bandung. Teknik analisis data yang dilakukan meliputi analisis data kualitatif dan kuantitatif. Temuan dalam penelitian ini adalah CCT terbukti efektif dalam meningkatkan karakter kreatif guru PAUD di Kecamatan Coblong Kota Bandung dalam indikator berpikir divergen, creative process, product, dan person. Hal ini dapat terlihat dari adanya peningkatan hasil uji pretes dan postes peserta dengan $\mathrm{N}$-Gain sebesar 0,75 yang menunjukkan tingkat signifikansi gain dalam kategori tinggi. CCT ini memberikan panduan kepada guru PAUD dalam menentukan kegiatan pembelajaran yang menarik dan mampu mengembangkan berbagai kemampuan anak sehingga guru PAUD mampu berinovasi dalam setiap pembelajaran dan memiliki karakter kreatif yang baik.
\end{abstract}

Kata Kunci: creative character training (cct); karakter kreatif; guru paud.

\begin{abstract}
This study aims to determine the impact of Creative Charter Training (CCT) on the improvement of creative character in Kindergarten teachers in Coblong District, Bandung City. This research uses Exploratory Sequential Mixed Methods Design. Participants in this study were 13 PAUD teachers in Coblong District, Bandung City. Data analysis techniques include qualitative and quantitative data analysis. The findings in this study are that CCT is proven to be effective in improving the creative character of early childhood teachers in Coblong District, Bandung City in indicators of divergent thinking, creative process, product, and person. This can be seen from the increase in the results of participants' pretest and posttest tests with an NGain of 0.75 which indicates a significant level of gain in the high category. This CCT guides PAUD teachers in determining interesting learning activities and being able to develop various children's abilities so that PAUD teachers can innovate in every lesson and have good creative character.
\end{abstract}

Keywords: creative character training (cct); creative character; kindergarten teacher.

Copyright (c) 2021 Iis Sumyati Shalihat, Syamsu Yusuf Lili Nanih , Uman Suherman Alamsyah

$\triangle$ Corresponding author: Iis Sumyati Shalihat

Email Address : iisshalihat@yahoo.com (Bandung, Jawa Barat, Indonesia)

Received 16 Januari 2021, Accepted 2 June 2021, Published 16 June 2021 


\section{PENDAHULUAN}

Kompetensi guru dipandang sebagai salah satu aspek penting dalam arus globalisasi dan industri 4.0 guna pengembangan dan transformasi pendidikan (Wulan, 2019; Wardani et al., 2020). Kompetensi ini berkaitan dengan kemampuan guru dalam merencanakan, melaksanakan, menilai proses dan hasil pembelajaran, serta melakukan bimbingan dan pelatihan kepada siswa sehingga menghasilkan proses dan hasil pendidikan yang bermutu (Judiani, 2011; Herminayu \& Sulasmono, 2020). Kompetensi guru dipengaruhi oleh berbagai faktor yang saling terkait, salah satunya adalah kreativitas. Kreativitas merupakan kemampuan untuk melakukan generalisasi ide, produk, dan tindakan yang original seorang individu (Taylor \& Getzels, 2017; Glăveanu, 2018). Dengan kreativitas, seseorang dapat melakukan pendekatan yang bervariasi serta memiliki berbagai macam kemungkinan penyelesaian terhadap suatu masalah. Guru yang mampu berpikir kreatif akan dapat menciptakan lingkungan belajar yang mendorong ssiwa lebih jauh untuk dapat berpikir kreatif pula.

Lembaga pendidikan sering mengidentifikasi kreativitas sebagai tujuan pembelajaran eksplisit dalam kebijakan pendidikan (Fischer, 2020). Hal ini menunjang ilmu pengetahuan yang berkembang saat ini dimana kemampuan berinovasi dianggap kemampuan nomor satu yang harus dimiliki oleh guru (Isaksen \& Akkermans, 2011), dan di mana sekolah harus mempersiapkan siswa untuk untuk belajar agar mampu memecahkan masalah di masa sekarang ataupun di masa yang akan datang yang bahkan tidak diketahui permasalahan seperti apa (Samandari et al., 2010). Namun, perhatian terhadap karakter kemampuan kreatif guru yang relatif sedikit, hal ini menjadikan kurangnya minat guru untuk meningkatkan karakter kreativitas dan berinovasi dalam pembelajaran, Data menunjukkan kreativitas masyarakat Indonesia berdasarkan survei pada Global Creativity Index 2015 berada pada peringkat 115 dari 139 negara (Florida et al., 2015). Indeks Kreativitas Global ini menilai indeks kreativitas suatu negara berdasarkan teknologi, talent, dan toleransi. Sementara itu, Global Innovation Index 2019 menempatkan Indonesia pada peringkat 85 dari 129 negara (Androschuk, 2021). Hasil ini pun masih menunjukkan posisi Indonesia masih di bawah dibandingkan dengan negara-negara Asia Tenggara dan Oseania lainnya (Pençe et al., 2019). Indeks kreativitas dan inovasi Indonesia yang rendah berkaitan dengan kualitas pendidikan yang masih perlu ditingkatkan, termasuk dalam jenjang Pendidikan Anak Usia Dini (PAUD). Pendidikan bagi anak usia dini menjadi bagian penting yang tidak dapat ditinggalkan dan mutlak harus terus ditingkatkan. Hasil riset menunjukkan kelompok anak yang mendapatkan layanan PAUD memiliki kemampuan pra-akademik dan skor akademik dalam IQ yang lebih baik (Arningsih, 2011; Lochman, 2012).

Beberapa ahli menemukan permasalahan terkait karakter kreativitas guru diantaranya Fischer (2020) menemukan bahwa kurangnya perhatian terhadap pengembangan krativitas guru dan solusinya adalah melibatkan Perguruan Tinggi untuk melakukan pengembangan kreativitas guru. Ata-Akturk \& Sevimli-Celik (2020) dalam penelitiannya membahas permasalahan terkait kurangnya pengetahuan dan pengalaman guru terkait kreativitas dalam mengajar. Penelitian lainnya menjelaskan bahwa kreativitas siswa tergantung pada pengalaman guru (Bereczki \& Kárpáti, 2018; Kettler et al., 2018; Lasky \& Yoon, 2020; Kupers \& van Dijk, 2020; Mahkamovna, 2020).

Selajan dengan temuan di atas, berdasarkan hasil observasi awal, permasalahan terkait karakter kreatifitas ditemukan pula pada guru PAUD kelas B di Kecamatan Coblong, Kota Bandung. Permasalahannya adalah sebagian guru merasa kesulitan dalam memilih kegiatan pembelajaran yang menarik untuk anak, membuat Rencana Pelaksanaan Pembelajaran Harian yang mampu mengembangkan seluruh aspek perkembangan anak, mengajarkan anak untuk berpikir divergen dan terkait membuat sebuah karya tulis ilmiah. Hal ini butuh penyelesaian yang tepat. 
Pembelajaran di PAUD pada dasarnya menekankan pada pengenalan dan penanaman karakter yang diperlukan untuk menjadi manusia di masa depan yang dapat memaksimalkan semua potensi dan kreativitas (Cahyaningrum et al., 2017; Sabardila et al., 2021). Produk dari kreatif ini akan dapat dihasilkan dari proses berpikir kreatif pada seseorang, yang ditunjang dengan sifat atau karakter kreatif. Karakter kreatif ini berkaitan erat dengan keinginan dan dorongan untuk terus menghasilkan ide-ide pemikiran yang kreatif (Wulan, 2019). Menurut Fakhriyani (2016), tiga kondisi dari pribadi yang memiliki karakter kreatif adalah: 1) keterbukaan terhadap pengalaman; 2) kemampuan untuk menilai situasi sesuai dengan patokan pribadi seseorang; dan 3) kemampuan untuk bereksperimen dan bermain dengan konsep. Sayangnya, karakter kreatif pada anak tidak mungkin dimunculkan jika guru juga tidak memiliki karakter kreatif. Perubahan karakter kreatif pada anak melalui guru menjadi alternatif strategi yang perlu dipertimbangkan dan memerlukan replikasi penelitian. Salah satu cara yang dapat dilakukan untuk meningkatkan karakter kreatif guru adalah dengan mengikuti program pelatihan karakter kreatif (Creative Character Training).

Pelatihan karakter kreatif menunjukkan kegiatan yang dirancang untuk menguatkan karakter kreatif guru melalui serangkaian proses yang terbagi atas beberapa bagian kegiatan (Byrge \& Tang, 2015). Telah ada beberapa kajian yang menghasilkan berbagai metode pelatihan penguatan kreativitas seperti brain-storming dan brain-writing (Alex F Osborn, 1963), berpikir lateral (De Bono, 1992), creative problem-solving (Taket et al., 1992), creative checklist (Davis \& Roweton, 1968), dan abarietic trainin (Karwowski \& Soszynski, 2008). Lebih lanjut kajian terbaru yang dilakukan oleh Byrge \& Tang (2015) mengenai embodied creativity training dan overinclusive thinking training (Chiu, 2015) menyarankan pelatihan yang bersifat praktis dan menuntut kemampuan berpikir peserta pelatihan. Jenis pelatihan semacam ini terbukti berpengaruh pada kemampuan kreativitas dan menguatkan karakter kreatif peserta pelatihan (Leritz et al., 2004; Lin, 1984). Oleh karena itu, Creative Character Training (CCT) yang diterapkan dalam penelitian ini berdasar dari integrasi antara embodied creativity training (Byrge \& Tang, 2015) dan overinclusive thinking training (Chiu, 2015) dengan tahapan kegiatan terdiri atas: a) introduction, b) creativity fitness exercise, c) workshop, d) creativity thinking test, dan e) theoritical reflection.

Oleh karena itu, dengan mengangkat permasalahan tersebut, penelitian ini akan mengeksplorasi dan membahas Creative Character Training (CCT), khususnya mengenai tahapan, proses, dan pengaruhnya terhadap karakter kreatif peserta pelatihan yang terdiri atas guru-guru PAUD. Dengan pemikiran tersebut, maka penelitian ini bertujuan untuk mengetahui dampak Creative Character Training (CCT) terhadap peningkatan karakter kreatif guru Taman Kanak-Kanak di Kecamatan Coblong Kota Bandung.

\section{METODOLOGI}

Penelitian ini menggunakan metode campuran dengan Exploratory Sequential Mixed Methods Design (Creswell, 2013). Eksploratory Sequential dipilih untuk mengeksplorasi, memahami dan mengelola data secara luas terkait hasil Character Crative Trainning (CCT) untuk meningkatkan karakter kreatif guru-guru TK di Kecamatan Coblong Kota Bandung. Indikator karakter kreatif yang diukur dalam penelitian mengacu pada indikator karakter kreatif Peterson, C. \& Seligman (2004) yaitu: a) berpikir divergen, b) creative proccess, c) creative product, dan d) creative person. Dalam penelitian ini, pertama-tama data kualitatif dikumpulkan dan dianalisis untuk mendorong pengembangan instrumen kuantitatif terkait karakter kreatif guru-guru TK di Kecamatan Coblong Kota Bandung. Dalam penelitian ini, data kualitatif dikumpulkan terlebih dahulu dan dianalisis untuk mendorong pengembangan instrumen kuantitatif terkait karakter kreatif guru-guru TK di Kecamatan Coblong Kota Bandung. Gambar 1 adalah bagan Exploratory Sequential Mixed Methods Design. 


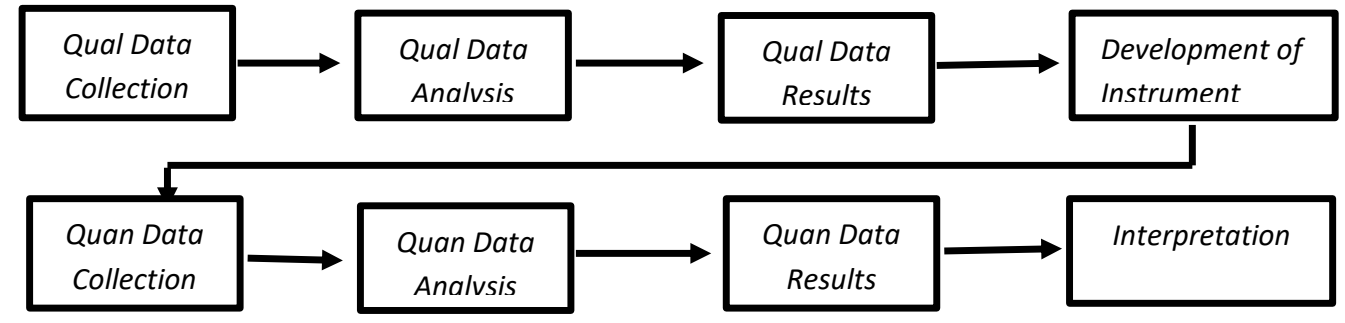

Gambar 1. Exploratory Sequential Mixed Methods Research Design (Creswell, 2013)

Partisipan dalam penelitian ini adalah 13 orang guru PAUD di Kecamatan Coblong, Kota Bandung. Partisipan dipilih berdasarkan kriteria: (1) bersedia menjadi informan, (2) kemudahan akses informasi ataupun sarana dan prasarana. Populasi dalam penelitian ini adalah seluruh guru PAUD di Kecamatan Coblong sebanyak 120 orang dari 10 PAUD. Teknik pengambilan sampel yang dilakukan peneliti dengan menggunakan random sampling. Penelitian ini dilaksanakan pada semester genap tahun ajaran 2020/2021 di PAUD wilayah Kecamatan Coblong.

Instrumen yang digunakan dalam penelitian ini adalah angket berupa wawancara untuk mengetahui profil karakter kreatif guru dan angket berupa lembar kerja untuk menilai kemampuan karakter kreatif guru. Studi dokumentasi juga dilakukan dalam penelitian ini. Studi dokumentasi dilakukan dengan cara menelaah buku-buku terkait karakter kreatif, menelaah media-media pembelajaran yang digunakan untuk anak usia dini, dokumen kurikulum 2013, buku dan artikel terkait pengembangan karakter kreatif guru. Hal ini dimaksudkan untuk mengembangkan instrument penilaian dan mengembangkan langkahlangkah pelatihan kreatifitas yang akan digunakan dalam kegiatan workshop.

Hasil studi dokumentasi ini adalah pola pelatihan baru untuk meningkatkan karakter kreatif guru yaitu Creative Character Training (CCT) yang merupakan gabungan dari dua jenis pelatihan kreativitas yang menjadi dasar pelaksanaan pelatihan dalam penelitian ini, yaitu Embodied Creativity Training (Byrge \& Tang, 2015). dan Overinclusive Thinking Training (Chiu, 2015). Sedangkan kisi-kisi penilaian karakter kreatif guru mengacu pada pendapat (Cloninger, 2005) dengan menggunakan penilaian skala Likert. Analisis data yang dilakukan dalam penelitian ini meliputi analisis data kualitatif dan kunatitatif. Analisis data secara kualitatif yang dilakukan adalah reduksi data, penyajian data, dan simpulan serta verifikasi. Sedangkan untuk analisis data kuantitatif, teknik analisis data yang digunakan adalah uji normalitas, uji homogenitas, dan uji beda dua rata-rata.

\section{HASIL DAN PEMBAHASAN}

Pelaksanaan Creative Character Training untuk Meningkatkan Karakter Kreatif Guru PAUD di Kecamatan Coblong Kota Bandung, Indonesia

Tahapan kegiatan dalam pelatihan ini yaitu: pembukaan, latihan kebugaran, workshop, tes kreativitas, refleksi. Aktivitas pada setiap tahap menggunakan beragam teknik dan strategi baik secara individual ataupun kelompok. Pelaksanaan setiap sesi intervensi dilakukan dalam ruang kelas atau secara daring dan jika memungkinkan untuk sesi tertentu pelaksanaannya di alam terbuka. Untuk pelaksanaan dalam ruang kelas, formasi duduk anggota kelompok tidak ditetapkan secara ketat karena yang penting adalah adanya rasa aman sehingga memungkinkan guru dapat berinteraksi secara nyaman dengan anak dan memudahkan untuk saling berbagi pengalaman dan memperoleh umpan balik, dalam penelitian ini pelatihan Creative Character Training (CCT) dilakukan secara daring selama 3 hari. Pelatihan ini dilaksanakan dari hari Kamis tanggal 3 Maret 2021 sampai hari Sabtu tanggal 5 Maret 2021. Meskipun dilakukan secara daring namun tidak mengurangi esensi dan kebermaknaan pelatihan Creative Character Training (CCT) ini. 
Dalam kegiatan pelatihan Creative Character Training (CCT) hubungan antara guru dengan anak lebih bersifat setara dan guru diharapkan bersikap terbuka dan mengajarkan anak untuk berpikir divergen. Guru diharapkan mampu membantu anak dalam melakukan kegiatan-kegiatan yang berbeda dari biasanya. Langkah-langkah pelaksanaan Creative Character Training (CCT) dijelaskan pada tabel 1 - 5.

\section{Tabel 1 Kegiatan Pembukaan dalam CCT}

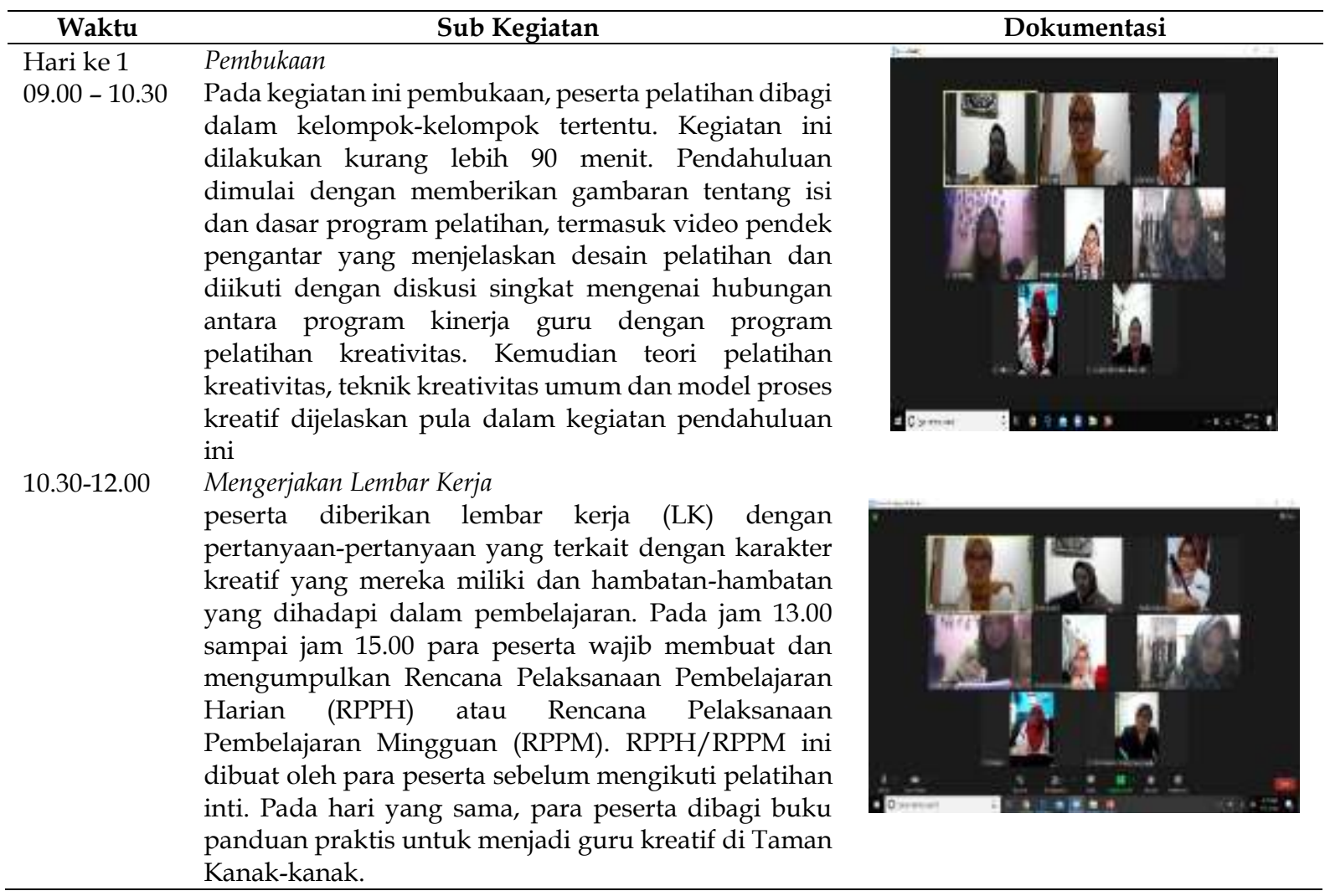

Tabel 2 Creativity Fitness Exercise dalam CCT

\begin{tabular}{|c|c|c|}
\hline Waktu & Sub Kegiatan & Dokumentasi \\
\hline $\begin{array}{l}\text { Hari ke } 2 \\
09.00-10.15\end{array}$ & $\begin{array}{l}\text { Creativity Fitness Exercise } \\
\text { kegiatan hari kedua ini diawali dengan } \\
\text { kegiatan Creativity Fitness Exercise. Kegiatan ini } \\
\text { bertujuan untuk meningkatkan fokus peserta pada } \\
\text { pelatihan. Kegiatan ini merupakan kegiatan yang } \\
\text { melibatkan fisik dan kemampuan berpikir kreatif } \\
\text { dan dilakukan secara berpasangan. Kegiatan } \\
\text { dipandu oleh narasumber dalam hal ini peneliti } \\
\text { sendiri yang menginstruksikan dan melakukan } \\
\text { peragaan singkat di depan para peserta pelatihan. } \\
\text { Pada sesi ini, para peserta bersama } \\
\text { narasumber melakukan brain game. Hal ini dilakukan } \\
\text { untuk menstimulasi agar daya konsentrasi para } \\
\text { peserta pelatihan menjadi lebih baik. Pada sesi ini } \\
\text { juga diberikan beberapa permainan yang berfungsi } \\
\text { untuk meningkatkan kemampuan kreativitas anak. } \\
\text { Kegiatan ini dilakukan dari jam } 09.00 \text { sampai jam } \\
\text { 10.00. dengan adanya kegiatan ini, maka para } \\
\text { peserta menjadi lebih fokus untuk mengokohkan } \\
\text { karakter kreatif yang telah dimiliki dengan cara } \\
\text { mengikuti tahapan-tahapan kegiatan yang peneliti } \\
\text { berikan. }\end{array}$ & \\
\hline
\end{tabular}




\section{Tabel 3 Kegiatan Workshop dalam CCT}

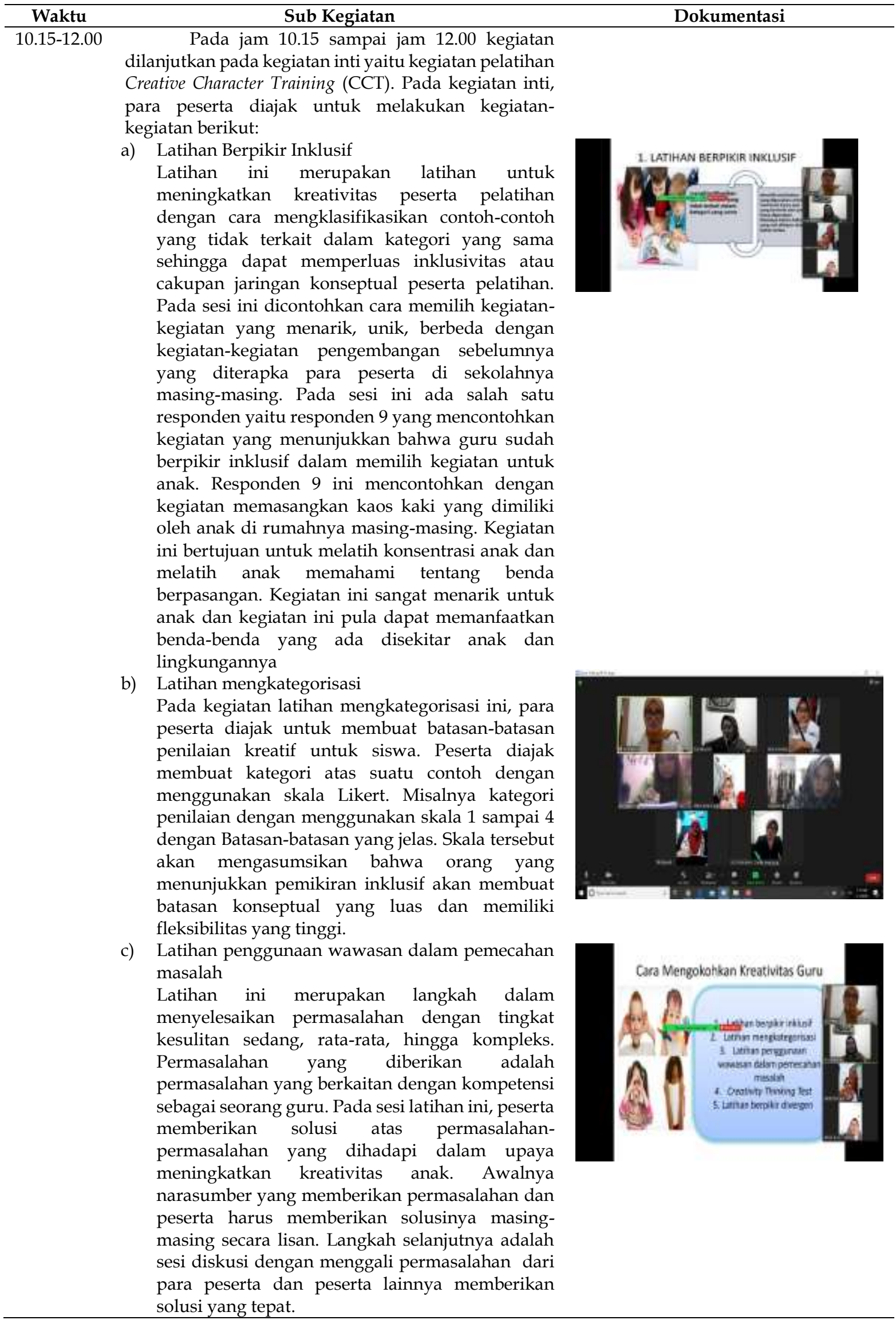




\section{Tabel 4 Kegiatan Tes Kreativitas dalam CCT}

\begin{tabular}{lll}
\hline \multicolumn{1}{c}{ Waktu } & \multicolumn{1}{c}{ Sub Kegiatan } \\
\hline Pukul 13.00 & Tes kreativitas ini berbentuk tes unjuk kerja atau \\
hingga & performansi yang memuat komponen-komponen \\
14.30 & $\begin{array}{l}\text { indikator berpikir kreatif seperti keluwesan, } \\
\text { orisinalitas, elaborasi, dsb. Para peserta diberikan } \\
\text { tugas untuk merencanakan RPPH/RPPM lengkap } \\
\text { dengan media pembelajaran yang akan digunakan } \\
\text { sesuai dengan arahan dari narasumber. Tema dan sub } \\
\text { tema yang digunakan ssesuai dengan arahan dari ahli } \\
\text { atau narasumber. Batas waktu pengumpulan tugas } \\
\text { pada sesi ini sampai jam 10.00 tanggal 5 Maret 2021. }\end{array}$ \\
\hline
\end{tabular}

Tabel 5 Kegiatan Refleksi Teoritis dalam CCT

\begin{tabular}{ll}
\hline \multicolumn{1}{c}{ Waktu } & \multicolumn{1}{c}{ Sub Kegiatan } \\
\hline Hari ke 3 & Kegiatan terakhir pada hari terakhir adalah refleksi \\
$10.00-12.00$ & teoritis. Kegiatan ini dilakukan selama dua jam yaitu \\
& dari jam 10.00 sampai jam 12.00. Peserta pelatihan \\
& dijadikan satu dalam sebuah ruangan besar. Refleksi \\
& teoritis dimulai dengan pemaparan atau kilas ulang \\
& materi yang diberikan pada hari kedua terkait \\
& landasan teori dari kreativitas dan teori pembelajaran. \\
& Kemudian dilanjutkan dengan diskusi tentang \\
& variabel-variabel yang penting untuk peningkatan \\
& kreativitas yang berkelanjutan baik dalam perspektif \\
& jangka pendek maupun jangka panjang.
\end{tabular}

\section{Dampak Creative Character Training (CCT) pada Peningkatan Karakter Kreatif Guru PAUD di Kecamatan Coblong Kota Bandung, Indonesia.}

Uji kreativitas guru ini dilakukan pada 13 orang guru PAUD yang berada di wilayah Kecamatan Coblong Kota Bandung. Guru-guru ini diberikan pre test sebelum mengikuti pelatihan Creative Character Training (CCT). Pre test dilakukan dengan maksud untuk mengetahui karakter kreatif dari guru-guru TK tersebut. Setelah diberikan perlakukan yaitu pelatihan Creative Character Training (CCT), maka guru-guru TK B ini diberikan posttest. Posttest ini dilakukan untuk mengetahui sejauhmana peningkatan kemampuan kreatif guruguru PAUD setelah mengikuti pelatihan.

Pada tahapan ini dilakukan uji normalitas dan homogenitas data pre test. Untuk uji normalitas, peneliti menggunakan uji Kolmogorov-Smirnov dengan software SPSS.22, untuk melihat distribusi data skor prates. Pengujian dilakukan dengan membandingkan probabilitas (sig.) dengan nilai alpha (a). Kriteria pengujian adalah apabila (Sig.) $>$ alpha (a), maka hasil tes dikatakan berdistribusi normal. Ketentuan pengujian normalitas dengan menggunakan Kolmogorov-Smirnov adalah jika angka signifikan (Sig.) $<0,05$, maka berdistribusi tidak normal, tapi jika angka signifikan (Sig.) $>0,05$ maka berdistribusi normal. Hasil uji normalitas data prates memiliki nilai Sig. > 0,05 yaitu Asymp. Sig. (2-tailed)=0,200. 
Pada penelitian ini tidak menggunakan kelas kontrol maka uji homogenitas tidak dilakukan, tapi langsung dilakukan uji $\mathrm{t}$ atau uji beda rata-rata menggunakan uji Analisis Paired-Samples T Test. Hipotesis pengujiannya adalah sebagai berikut :

Ho: Tidak terdapat perbedaan rata-rata skor pre test dan posttest.

H1: Terdapat perbedaan rata-rata skor pada pre test dan posttest.

Dengan kriteria pengujian, jika angka $\mathrm{p}>0,05$, maka Hipotesis Ho diterima dan H1 ditolak. Untuk menguji tingkat signifikasinya dapat dilakukan dengan membandingkan antara probabilitas sig. dengan nilai alpha (a). Jika nilai probabilitas $>$ nilai $a$, maka tidak signifikan, sebaliknya jika nilai probabilitas sig. < nilai a maka signifikan. Adapun hasil uji t hasil pre test dan posttest dijelaskan pada tabel 6.

Tabel 6 Rata-Rata Data Pre Test dan Posttest Karakter Kreatif Guru-Guru PAUD di Kecamatan Coblong

\section{Paired Samples Statistics}

\begin{tabular}{llcrrr}
\hline & & Mean & N & Std. Deviation & Std. Error Mean \\
\hline Pair 1 & pretest & 39.62 & 13 & 2.873 & .797 \\
& postest & 55.23 & 13 & 2.682 & .744 \\
\hline
\end{tabular}

Data di atas menunjukkan bahwa hasil uji rata-rata pre test karakter kreatif guru TK $B$ atau mean sebesar 39.62. Sedangkan hasil uji rata-rata posttest karakter kreatif guru PAUD diperoleh mean sebesar 55,23. Untuk jumlah responden sebanyak 13 orang guru PAUD. Diperoleh nilai standar deviasi pada pre test sebesar 2,873 dan pada posttest sebesar 2,682, sedangkan nilai standar error mean pada pre test sebesar 0,797 dan pada posttest diperoleh nilai sebesar 0,744. Dari perolehan data di atas dapat disimpulkan bahwa secara deskriptif ada perbedaan rata-rata karakter kreatif antara hasil pre test dengan hasil postest. Untuk mengetahui bahwa terdapat pengaruh pelatihan Creative Character Training (CCT) maka dilakukan uji beda rata-rata. Secara rinci dijelaskan pada tabel di bawah ini.

\section{Tabel 7 Hasil Uji Beda Rata-Rata Pre Test dan Posttest Karakter Kreatif Guru-Guru PAUD di Kecamatan Coblong}

\begin{tabular}{|c|c|c|c|c|c|c|c|c|}
\hline \multicolumn{9}{|c|}{ Paired Samples Test } \\
\hline & \multicolumn{5}{|c|}{ Paired Differences } & \multirow[b]{3}{*}{$\mathrm{t}$} & \multirow[b]{3}{*}{$\mathrm{df}$} & \multirow{3}{*}{$\begin{array}{l}\text { Sig. (2- } \\
\text { tailed) }\end{array}$} \\
\hline & \multirow{2}{*}{ Mean } & \multirow{2}{*}{$\begin{array}{c}\text { Std. } \\
\text { Deviation }\end{array}$} & \multirow{2}{*}{$\begin{array}{l}\text { Std. } \\
\text { Error } \\
\text { Mean }\end{array}$} & \multicolumn{2}{|c|}{$\begin{array}{l}95 \% \text { Confidence } \\
\text { Interval of the } \\
\text { Difference }\end{array}$} & & & \\
\hline & & & & Lower & Upper & & & \\
\hline \begin{tabular}{l|l|} 
Pair 1 & pretest - postest \\
\end{tabular} & -15.615 & 4.053 & 1.124 & -18.064 & -13.166 & -13.893 & 12 & .000 \\
\hline
\end{tabular}

Dari data tabel 6 diperoleh nilai sig. (2-tailed) sebesar 0,000<0,005. Dari perolehan nilai tersebut dapat disimpulkan bahwa terdapat pengaruh yang signifikan pelatihan Creative Character Training (CCT) terhadap karakter kreatif yang dimiliki oleh guru TK B Kecamatan Coblong Kota Bandung. Secara umum perbedaan peningkatan (Gain) karakter kreatif guru PAUD di Kecamatan Coblong dapat dihitung sebagai berikut:

$$
N-\text { Gain }=\frac{714-515}{780-515}=0,75
$$

Kategori tingkatan gain adalah jika g>0,7, maka tingkat signifikan gain dinyatakan dalam kategori tinggi, jika 0,03 $\leq \mathrm{g} \leq 0,7$ maka tingkatan gain dinyatakan dalam kategori sedang dan jika $\mathrm{g}<0,3$ maka tingkatan gain dalam kategori rendah. Dari data di atas dapat disimpulkan bahwa tingkatan gain yang diperoleh dikategorikan tinggi karena $g>0,07$ yaitu 0,75 . 


\section{Pembahasan}

Kegiatan pelatihan Creative Character Training (CCT) ini dimaksudkan membantu guru PAUD untuk menjadi lebih kreatif. Pada tahap inti pelatihan, peserta dilatih berpikir divergen membuat respons menjadi lebih kreatif. Dan latihan berpikir divergen ini salah satu penemuan tertua dalam ilmu kreativitas. Dalam penelitian Nasbaum tersebut dilakukan sebuah eksperimen mengukur kecerdasan cair dan memberikan 2 tugas berpikir yang berbeda: orang menyelesaikan satu dengan instruksi "menjadi kreatif" dan yang lainnya dengan instruksi "menjadi fasih" (menghasilkan ide sebanyak mungkin). Namun yang paling berperan meningkatkan kemampuan kreatif adalah latihan berpikir divergen (Astana et al., 2020). Ada beberapa pendapat yang mendukung temuan terkait meningkatkan karakter kreatif dintaranya adalah pelatihan kreativitas melalui kursus online berbasis metode proyek (Kaplan, 2019). Langkah-langkah dalam kursus online ini salah satunya adalah kerangka kerja yang memandu desain, konten pemikiraanakn kritis, tugas berbasis konstruksi yang dimaksudkan untuk melibatkan penggunaan teori dalam desain, dan komunikasi kolaboratif. Pelaksanaan kursus online berbasis proyek ini didukung oleh banyak wacana tentang kreativitas di lembaga pendidikan internasional (Hall, 2010; Wyse \& Ferrari, 2015).

Kajian di atas sesuai dengan pelaksanaan kegiatan pelatihan Creative Character Training (CCT) dilakukan secara daring dengan langkah-langkah yang tepat. Hal ini terbukti dari antusias peserta yang mengikuti setiap tahapan pelatihan untuk meningkatkan karakter kreatif ini. Adapun program yang dilatihkan dalam pelatihan ini adalah (1) Latihan berpikir inklusif, (2) Latihan mengkategorisasi menggunakan skala Likert, (3) Latihan penggunaan wawasan dalam pemecahan masalah dan (4) Tes kemampuan berpikir kreatif (berpikir divergen). Hal ini didasari oleh pendapat yang menjelaskan bahwa produk kreatif akan dapat dihasilkan dari proses berpikir kreatif pada individu, yang ditunjang oleh sifat kreatif atau ciri-ciri afektif dari individu tersebut yang berkaitan erat dengan keinginan dan dorongan seorang untuk terus menghasilkan ide-ide pemikiran yang kreatif (Wulan, 2019).

Karakter kreatif ini merupakan kemampuan yang harus dimiliki guru dalam hal ini dikhususkan untuk guru PAUD. Karena dengan karakter kreatif yang baik maka sekolahnya akan mempunyai daya saing yang baik juga. Krativitas adalah sebuah bagian penting dari inovasi organisasi (Amabile \& Khaire, 2008). Oleh karena itu, meningkatkan kreativitas telah menjadi perhatian kritis; khususnya, bagaimana orang menghasilkan kreatif ide dan solusi telah menarik banyak perhatian (Roskes et al., 2012). Untuk meningkatkan studi kreativitas, banyak peneliti telah mengembangkan metode untuk meningkatkan kreativitas (Nusbaum et al., 2014; Oppezzo \& Schwartz, 2014; Chiu, 2015; Byrge \& Tang, 2015; Bereczki \& Kárpáti, 2018; Rubenstein et al., 2018).

Dalam langkah-langkah pelatihan Creative Character Training (CCT) ini, peneliti mengadopsi langkah-langkah pelatihan yang dikembangkan oleh embodied creativity training (Byrge \& Tang, 2015) dan overinclusive thinking training (Chiu, 2015) agar menjadi sebuah model pelatihan baru yang dapat dikembangkan untuk meningkatkan kemampuan karakter kreatif guru TK. Beberapa temuan hal di atas berkaitan dengan kreativitas dijelaskan oleh beberapa ahli diantaranya diantaranya ditemukan bahwa guru menekankan karakteristik kreatif yang berbeda (Kettler et al., 2018), istilah kreatif ini didefinisikan oleh beberapa ahli adalah lebih ditekankan pada kefasihan (Jonathan A. Plucker et al., 2004), fleksibilitas (Kang Sup et al., 2003), elaborasi (Torrance, 1979), keterbukaan terhadap pengalaman baru (Liu \& Lin, 2014), impulsivitas atau petualangan (Kampylis et al., 2011), dan sebagai kritis atau emosional (Aljughaiman \& Mowrer-Reynolds, 2005).

Hal ini sesuai dengan pemilihan berbagai kegiatan yang mencerminkan karakter kreatif guru (Na'imah et al., 2020). Beberapa contoh kegiatan yang menunjukkan bahwa guru PAUD ini memiliki karakter kreatif yang tinggi diantaranya adalah memindahkan air ke dalam botol dengan menggunakan spon, membuat belalai gajah dari air sulight dan kaos kaki, membuat bentuk topi menggunakan playdough, dan melipat topi menggunakan kertas koran (anak boleh menggunakan bahan selain koran). Adapun media yang digunakan adalah media 
dari barang bekas seperti kardus, bahan plastik, bekas botol minuman dll. Selain itu digunakan juga bahan dari loose part. Namun pemilihan media ini disesuaikan dengan bahan-bahan dan alat-alat yang ada di rumahnya masing-masing. Karakter kreatif guru PAUD di Kecamatan Coblong ini dapat berkembang dengan baik karena dipengaruhi oleh beberapa hal diantaranya adalah motivasi dalam belajar hal-hal baru, mengikuti langkahlangkah yang diberikan dalam pelatihan dengan baik, lembaga yang mendukung pengembangan kegiatan kreativitas dan sarana prasarana yang mendukung.

Pelatihan karakter kreativitas guru tidak hanya dilakukan oleh peneliti, tapi telah dilakukan oleh ahli-ahli sebelumnya diantaranya peningkatan kemmapuan guru dalam hal kreativitas dilakukan melalui kursus dan materi pengembangan profesional ditawarkan secara online dan offline di seluruh dunia (Beghetto \& Kaufman, 2014; Plucker et al., 2015). Pembelajaran kreativitas ini memang banyak mengambil resiko, ditetapkan melalui kesediaan untuk mencoba ide dan kemungkinan baru, dan terlibat dengan potensi kegagalan, adalah kunci sifat berulang kreativitas dan pembelajaran (Beghetto, 2019). Namun peneliti mencoba ide baru ini dengan mengkolaborasikan antara langkah-langkah dalam embodied creativity training (Byrge \& Tang, 2015), overinclusive Thinking Training (Chiu, 2015) dengan harapan dapat meningkatkan karakter kreatif guru PAUD.

Hasil dari pelatihan Creative Character Training (CCT) ini hasilnya dikategorikan dalam 3 level yaitu tinggi, sedang dan rendah. Hasil penilaian ini sangat ditentukan oleh karakter kreatif yang dimiliki oleh guru tersebut. Salah satu contohnya adalah indikator 15 yaitu memiliki kemampuan menulis karya tulis ilmiah yang dipublikasikan dalam satu semester atau satu tahun ataupun tidak dipublikasikan. Dalam hal ini sebagian besar guru PAUD di Kecamatan Coblong belum memahami yang dimaksud dengan karya tulis ilmiah pada waktu dilakukan pre test. Namun setelah dilakukan pelatihan karakter kreatif ini, guruguru PAUD ini menjadi paham terkait hal tersebut. Namun hanya ada satu orang responden yang menghasilkan karya tulis selama satu semester ini namun belum dipublikasikan yaitu berupa synopsis. Dan responden yang lainnya, karya tulis ini dihasilkan dalam waktu satu tahun namun belum dipublikasikan. Namun hal ini dijadikan tantangan bagi mereka.

Beberapa penelitian kreativitas yang ada telah mencatat bahwa orang-orang kreatif mendemonstrasikan keterbukaan terhadap pengalaman (Harris, 2004), bahkan ketika ada adalah potensi hasil atau kegagalan yang tidak pasti. Pengambilan risiko yang kreatif adalah bukan tentang perilaku berbahaya atau berisiko, tetapi orientasi kepada hal baru dan belajar melalui kesalahan atau tantangan. Kajian yang berkembang telah berfokus pada faktor-faktor yang mendukung atau menghambat risiko kreatif dalam pengajaran dan pembelajaran (Henriksen et al., 2021). dan masa depan. Hal ini termasuk kondisi pada tahun 2020 dan 2021 ini para guru mengalami kebingungan bagaimana cara menerapkan kreativitas dalam pembelajaran. Hal ini karena terjadi pergeseran pembelajaran jarak jauh dan penggunaan teknologi yang tepat dalam menghadapi pandemi COVID-19.

Hal ini telah menunjukkan betapa pentingnya inovasi untuk praktik pendidikan di tengah-tengah perubahan. Hal ini menunjukkan perlunya pengokohan karakter kreatif dari tenaga pendidik khususnya guru PAUD (Agustin et al., 2020). Pendidik diharapkan menjadi terbuka untuk ide-ide baru, risiko kreatif, dan kemauan untuk merangkul kebaruan (bahkan dengan hasil yang tidak pasti), dalam mengejar solusi untuk anak didik. Meskipun demikian, pengambilan risiko dan kreativitas secara inheren terikat pada ketakutan dan kegagalan karena potensi inisiatif baru itu bisa saja kurang tepat (Beghetto, 2019).

Dilihat dari kondisi dan kompetensi peserta pelatihan, secara umum media pembelajaran yang digunakan dan dibuat oleh peserta pelatihan sudah dinilai kreatif oleh instruktur. Namun, ada kalanya peserta pelatihan kurang memiliki motivasi untuk meningkatkan karakter kreatifnya, baik motivasi secara intrinsik maupun ekstrinsik. Terkait dengan hambatan-hambatan yang dialami peneliti hal ini selaras dengan penelitian dari AtaAkturk \& Sevimli-Celik (2020) yang menyelidiki persepsi guru PAUD tentang hambatan pendidikan kreativitas. Temuan dalam penelitian ini menunjukkan adanya tekanan dari orang 
tua menuntut untuk melihat produk, dan hal ini merupakan beban administrasi yang dihadapi oleh guru, dan keterbatasan pengetahuan dan keterampilan guru tentang kreativitas merupakan hambatan yang paling sering ditemukan.

\section{SIMPULAN}

Creative Character Training (CCT) terbukti efektif dalam meningkatkan karakter kreatif guru TK di Kecamatan Coblong Kota Bandung. Hal ini dapat terlihat dari adanya peningkatan hasil uji pretes dan postes peserta dengan N-Gain sebesar 0,75 yang menunjukkan tingkat signifikansi gain dalam kategori tinggi. Hambatan yang ditemukan dalam penelitian ini berkaitan dengan teknis pelaksanaan yang menyangkut rendahnya jaringan internet peserta, dalam sarana dan prasarana yang berkaitan dengan ketidakmampuan peserta dalam mengoperasikan perangkat, dalam penerapan kepada anak yang menyangkut kerjasama guru dan orang tua yang kurang konsisten, dan dilihat dari kondisi dan kompetensi peserta pelatihan yang dinilai kurang memiliki motivasi secara intrinsik maupun ekstrinsik.

\section{UCAPAN TERIMA KASIH}

Kepada Ketua IGTKI Kecamatan Coblong dan para guru TK yang telah berkontribusi dalam penelitian ini.

\section{DAFTAR PUSTAKA}

Agustin, M., Puspita, R. D., Nurinten, D., \& Nafiqoh, H. (2020). Tipikal Kendala Guru PAUD dalam Mengajar pada Masa Pandemi Covid 19 dan Implikasinya. Jurnal Obsesi : Jurnal Pendidikan Anak Usia Dini, 5(1), 334. https:/ / doi.org/10.31004/obsesi.v5i1.598

Alex F Osborn. (1963). Applied Imagination - Principles and Procedures of Creative Writing. In Charles Scribeners Sons, New York. https://www.scribd.com/book/262694054/Applied-Imagination-Principles-andProcedures-of-Creative-Writing

Aljughaiman, A., \& Mowrer-Reynolds, E. (2005). Teachers' conceptions of creativity and creative students. Journal of Creative Behavior, 39(1), 17-34. https://doi.org/10.1002/j.2162-6057.2005.tb01247.x

Amabile, T. M., \& Khaire, M. (2008). Creativity and the role of the leader. Harvard Business Review, 86(10).

Androschuk, G. (2021). Global innovation index 2020: who will finance innovations. Law and Innovations, 1 (33), 7-13. https:/ / doi.org/10.37772/2518-1718-2021-1(33)-1

Arningsih, C. (2011). Identifikasi Perkembangan Pra Akademik pada Balita oleh Kader Posyandu. Jassi Anakku, 10(2), 176-183.

Astana, A. C., Syafrina, R., \& Karnadi, K. (2020). Pengaruh Pretend Play dan Jenis Kelamin terhadap Kemampuan Berpikir Divergen Anak Usia 5-6 Tahun. Jurnal Obsesi : Jurnal Pendidikan Anak Usia Dini, 4(2), 597. https://doi.org/10.31004/obsesi.v4i2.417

Ata-Akturk, A., \& Sevimli-Celik, S. (2020). Creativity in early childhood teacher education: beliefs and practices. International Journal of Early Years Education, 0(0), 1-20. https://doi.org/10.1080/09669760.2020.1754174

Beghetto, R. A. (2019). Creativity in classrooms. In The Cambridge Handbook of Creativity: Second Edition (pp. 587-606). London: Cambridge University Press. https://doi.org/10.1017/9781316979839.029

Beghetto, R. A., \& Kaufman, J. C. (2014). Classroom contexts for creativity. High Ability Studies, 25(1), 53-69. https://doi.org/10.1080/13598139.2014.905247

Bereczki, E. O., \& Kárpáti, A. (2018a). Teachers' beliefs about creativity and its nurture: A systematic review of the recent research literature. In Educational Research Review (Vol. 23, pp. 25-56). Elsevier Ltd. https://doi.org/10.1016/j.edurev.2017.10.003 
Bereczki, E. O., \& Kárpáti, A. (2018b). Teachers' beliefs about creativity and its nurture: A systematic review of the recent research literature. In Educational Research Review (Vol. 23, pp. 25-56). https://doi.org/10.1016/j.edurev.2017.10.003

Byrge, C., \& Tang, C. (2015). Embodied creativity training: Effects on creative self-efficacy and creative production. Thinking Skills and Creativity, 16, 51-61. https://doi.org/10.1016/j.tsc.2015.01.002

Cahyaningrum, E. S., Sudaryanti, S., \& Purwanto, N. A. (2017). Pengembangan Nilai-Nilai Karakter Anak Usia Dini Melalui Pembiasaan Dan Keteladanan. Jurnal Pendidikan Anak, 6(2), 203-213. https:// doi.org/10.21831/jpa.v6i2.17707

Chiu, F. C. (2015). Improving your creative potential without awareness: Overinclusive thinking training. Thinking Skills and Creativity, 15, 1-12. https:// doi.org/10.1016/j.tsc.2014.11.001

https:// doi.org/10.1016/j.tsc.2014.11.001

Cloninger, C. R. (2005). Character Strengths and Virtues: A Handbook and Classification. American Journal of Psychiatry, 162(4), 820-a-821. https://doi.org/10.1176/appi.ajp.162.4.820-a

Creswell, J. W. (2013). Research Design Pendekatan Penelitian Kualitatiif, Kuantitatif, dan Mixed. 1-308. file:// / :/Users/Hp/Documents/buku creswell.pdf

Davis, G. A., \& Roweton, W. E. (1968). Using Idea Checklists With College Students: Overcoming Resistance. Journal of Psychology: Interdisciplinary and Applied, 70(2), 221-226. https:// doi.org/10.1080/00223980.1968.10544953

De Bono, E. (1992). Serious Creativity: Using the Power of Lateral Thinking to Create New Ideas. In Organizational Dynamics.

Fakhriyani, D. V. (2016). Pengembangan Kreativitas Anak Usia Dini. Wacana Didaktika, 4(2), 193-200. https://doi.org/10.31102/wacanadidaktika.4.2.193-200

Fischer, B. M. (2020). Developing and sustaining creativity: Creative processes in Canadian junior college teachers. Thinking Skills and Creativity, 38(July), 100754. https:// doi.org/10.1016/j.tsc.2020.100754

Florida, R., Mellander, C., \& King, K. (2015). The Global Creativity Index 2015. In Martin Prosperity Institute. http://martinprosperity.org/media/Global-Creativity-Index2015.pdf

Glăveanu, V. P. (2018). Educating which creativity? Thinking Skills and Creativity, 27, 25-32. https:// doi.org/10.1016/j.tsc.2017.11.006

Hall, C. (2010). Creativity in recent educational discourse in England. World Englishes, 29(4), 481-492. https://doi.org/10.1111/j.1467-971X.2010.01676.x

Henriksen, D., Henderson, M., Creely, E., Carvalho, A. A., Cernochova, M., Dash, D., Davis, T., \& Mishra, P. (2021). Creativity and risk-taking in teaching and learning settings: Insights from six international narratives. International Journal of Educational Research Open, 2-2(November 100024. https://doi.org/10.1016/j.ijedro.2020.100024

Herminayu, H., \& Sulasmono, B. S. (2020). Pengembangan Modul Pelatihan Model Pembelajaran BCCT Bagi Guru dan Kepala Taman Kanak-Kanak. Jurnal Obsesi : Jurnal Pendidikan Anak Usia Dini, 4(2), 1112. https://doi.org/10.31004/obsesi.v4i2.512

Isaksen, S. G., \& Akkermans, H. J. (2011). Creative climate: A leadership lever for innovation. Journal of Creative Behavior, 45(3), 161-187. https://doi.org/10.1002/j.21626057.2011.tb01425.x

Judiani, S. (2011). Kreativitas Dan Kompetensi Guru Sekolah Dasar. Jurnal Pendidikan Dan Kebudayaan, 17(1), 56. https:// doi.org/10.24832/jpnk.v17i1.7

Kampylis, P., Saariluoma, P., \& Berki, E. (2011). Fostering Creative Thinking-What do Primary Teachers Recommend? Hellenic Journal of Music, Education, 2(1), 46-64. 
Kang Sup, L., Dong-jou, H., \& Jong Jin, S. (2003). A development of the test for mathematical creative problem solving ability. Journal of the Korea Society of Mathematical Education Series D: Research in Mathematical Education, 7(3), 163-189.

Kaplan, D. E. (2019). Creativity in Education: Teaching for Creativity Development. Psychology, 10(02), 140-147. https:/ / doi.org/10.4236/psych.2019.102012

Karwowski, M., \& Soszynski, M. (2008). How to develop creative imagination?. Assumptions, aims and effectiveness of Role Play Training in Creativity (RPTC). Thinking Skills and Creativity, 3(2), 163-171. https://doi.org/10.1016/j.tsc.2008.07.001

Kettler, T., Lamb, K. N., Willerson, A., \& Mullet, D. R. (2018). Teachers' Perceptions of Creativity in the Classroom. Creativity Research Journal, 30(2), 164-171. https://doi.org/10.1080/10400419.2018.1446503

Kupers, E., \& van Dijk, M. (2020). Creativity in interaction: the dynamics of teacher-student interactions during a musical composition task. Thinking Skills and Creativity, 36(November 2019), 100648. https:// doi.org/10.1016/j.tsc.2020.100648

Lasky, D., \& Yoon, S. (2020). A creative classroom for everyone: An introduction to a small ' $c$ ' creativity framework. Thinking Skills and Creativity, 36, 100660. https://doi.org/10.1016/j.tsc.2020.100660

Leritz, L. E., Mumford, M. D., \& Scott, G. E. (2004). Types of Creativity Training: Approaches and Their Effectiveness. Journal of Creative Behavior.

Lin, H. -T. (1984). A Meta-Analysis of Long-Term Creativity Training Programs. The Journal of Creative Behavior, 18(1), 11-22. https:// doi.org/10.1002/j.2162-6057.1984.tb00985.x

Liu, S. C., \& Lin, H. shyang. (2014). Primary Teachers' beliefs about Scientific Creativity in the Classroom Context. International Journal of Science Education, 36(10), 1551-1567. https:// doi.org/10.1080/09500693.2013.868619

Lochman, J. E. et. al. (2012). Effective Daycare-Kindergarten Interventions to Prevent Chronic Aggression. Encyclopedia on Early Childhood Development. USA: The University of Alabama.

Mahkamovna, R. M. (2020). Challenges Of Creativity And Competence Of Children In Early Childhood Education. The American Journal of Social Science and Education Innovations, 02(10), 205-212. https:// doi.org/10.37547/tajssei/Volume02Issue10-34

Na'imah, T., Widyasari, Y., \& Herdian, H. (2020). Implementasi Sekolah Ramah Anak untuk Membangun Nilai-Nilai Karakter Anak Usia Dini. Jurnal Obsesi : Jurnal Pendidikan Anak Usia Dini, 4(2), 747. https:// doi.org/10.31004/obsesi.v4i2.283

Nusbaum, E. C., Silvia, P. J., \& Beaty, R. E. (2014). Ready, set, create: What instructing people to "be creative" reveals about the meaning and mechanisms of divergent thinking. Psychology of Aesthetics, Creativity, and the Arts, 8(4), 423-432. https://doi.org/10.1037/a0036549

Oppezzo, M., \& Schwartz, D. L. (2014). Give your ideas some legs: The positive effect of walking on creative thinking. Journal of Experimental Psychology: Learning Memory and Cognition, 40(4), 1142-1152. https:// doi.org/10.1037/a0036577

Pençe, I., Kalkan, A., \& Çeşmeli, M. Ş. (2019). Estimation of the Country Ranking Scores on the Global Innovation Index 2016 Using the Artificial Neural Network Method. International Journal of Innovation and Technology Management, 16(4). https://doi.org/10.1142/S0219877019400078

Peterson, C., \& Seligman, M. E. P. (2004). Character Strengths and Virtues: A Handbook and Classification. Oxford University Press; NewYork: Oxford University Press.

Plucker, J.A., Kaufman, J., \& Beghetto, R. (2015). What we know about creativity - 4Cs research series. Part of the 4 Cs Research Series.

Plucker, Jonathan A., Beghetto, R. A., \& Dow, G. T. (2004). Why isn't creativity more important to educational psychologists? Potentials, pitfalls, and future directions in creativity $\begin{array}{llll}\text { research. } & \text { Educational } & \text { 839(2), }\end{array}$ https://doi.org/10.1207/s15326985ep3902_1 
Roskes, M., De Dreu, C. K. W., \& Nijstad, B. A. (2012). Necessity is the mother of invention: Avoidance motivation stimulates creativity through cognitive effort. Journal of Personality and Social Psychology, 103(2), 242-256. https://doi.org/10.1037/a0028442

Rubenstein, L. D. V., Ridgley, L. M., Callan, G. L., Karami, S., \& Ehlinger, J. (2018). How teachers perceive factors that influence creativity development: Applying a Social Cognitive Theory perspective. Teaching and Teacher Education, 70, 100-110. https:// doi.org/10.1016/j.tate.2017.11.012

Sabardila, A., Markhamah, M., Arifin, Z., Kusmanto, H., Hidayah, L. N., Kurniasari, A. D., \& Saputro, D. (2021). Menakar Nilai Pendidikan Karakter Acara Televisi pada Anak Usia 6-8 Tahun. Jurnal Obsesi: Jurnal Pendidikan Anak Usia Dini, 6(1), 150-162. https:// doi.org/10.31004/obsesi.v6i1.875

Samandari, G., Speizer, I. S., \& O'Connell, K. (2010). The role of social support and parity on contraceptive use in Cambodia. International Family Planning Perspectives, 36(3), $122-$ 131. https:// doi.org/10.1363/3612210

Taket, A., Flood, R. L., \& Jackson, M. C. (1992). Creative Problem Solving: Total Systems Intervention. The Journal of the Operational Research Society, 43(10), 1013. https:// doi.org/10.2307/2584556

Taylor, I. A., \& Getzels, J. W. (2017). Perspectives in creativity. In Perspectives in Creativity. https:// doi.org/10.4324/9781315126265

Torrance, E. P. (1979). The Search for Satori and Creativity. New York: Creative Education Foundation.

http://buddhism.lib.ntu.edu.tw/DLMBS/en/search/search_detail.jsp?seq=286616

Wardani, D. S., Fauzi, M. R., Zafira, R., \& Kurniawati, D. (2020). Creating Props: Improving Writing Skills of Teaching Materials of Elementary Teacher Education Students through Project-Based Learning Model. Mimbar Sekolah Dasar, 7(2), 216-234. https:// doi.org/10.17509/mimbar-sd.v7i2.26334

Wulan, D. K. (2019). Rancangan Program Pelatihan Karakter Kreatif Pada Anak Usia Dini. Jurnal Penelitian Dan Pengukuran Psikologi, 8(2), 76-81. https://doi.org/10.21009/JPPP

Wyse, D., \& Ferrari, A. (2015). Creativity and education: Comparing the national curricula of the states of the European Union and the United Kingdom. British Educational Research Journal, 41(1), 30-47. https://doi.org/10.1002/ berj.3135 